\title{
POLA PEMASARAN INDUSTRI KERAJINAN BAMBU DI KABUPATEN SLEMAN
}

\author{
Henny Mulandari ${ }^{1}$, Sri Rahayu Budiani ${ }^{2}$ \\ 1Fakultas Geografi, Universitas Gadjah Mada \\ Sekip Utara Jalan Kaliurang, Bulaksumur, Yogyakarta, 55281, Indonesia \\ Email: henny.mulandari@mail.ugm.ac.id
}

\begin{abstract}
Abstrak
Industri kerajinan merupakan salah satu daya tarik pariwisata di Indonesia. Kabupaten Sleman memiliki industri kerajinan bambu terbanyak di Daerah Istimewa Yogyakarta. Tujuan penelitian ini adalah: (1) Mengetahui jenis kerajinan bambu terbanyak di Kabupaten Sleman; (2) Mengetahui pola pemasaran industri kerajinan bambu di Kabupaten Sleman; dan (3) Mengetahui strategi pemasaran kaitannya dengan keunggulan bersaing. Penelitian ini menggunakan metode kuantitatif dan kualitatif menggunakan kuesioner sebanyak 87 sampel. Metode mix kualitatif dan kuantitatif digunakan untuk memperoleh data deskriptif dari hasil olahan data secara persentase. Hasil penelitian ini menunjukkan bahwa Jenis produk kerajinan bambu di Kabupaten Sleman terdiri dari mebel bambu, gedek dan anyaman kepang, perabotan rumah tangga dari bambu, dan souvenir dari bambu. Jenis produksi kerajinan bambu yang paling di Kabupaten Sleman adalah besek. Pola pemasaran kerajinan bambu yang ada di Kabupaten Sleman terbagi menjadi enam pola pemasaran. Pola pemasaran yang digunakan oleh pengusaha berdasarkan jenis produk kerajinan bambu bervariasi. Pengusaha dapat melakukan berbagai macam alternatif strategi pemasaran yang dihasilkan dari perumusan strategi dengan matriks SWOT.
\end{abstract}

Kata kunci: : industri kerajinan bambu, pola pemasaran, strategi pemasaran.

\begin{abstract}
The craft industry is one of the attractions of tourism in Indonesia. Sleman Regency has the most bamboo handicraft industry in Special Region of Yogyakarta. The objectives of this research are: (1) Knowing the most types of bamboo crafts in Sleman Regency. (2) Knowing the marketing pattern of the bamboo craft industry in Sleman Regency, and (3) Knowing the marketing strategies related to competitive advantage. This study uses quantitative and qualitative, mix methods using questionnaires as many as 87 samples. Qualitative and quantitative methods are used to obtain descriptive data from the percentage of processed data. The results of the research show that Type of bamboo craft products in Sleman Regency consist of bamboo furniture, gedek and anyaman kepang, household bamboo furniture, and bamboo souvenirs. The most type of bamboo craft products in Sleman Regency are besek. The marketing pattern of the bamboo craft industry in Sleman Regency is divided into six patterns. The marketing pattern used by entrepreneurs based on the types of bamboo carft products varies. Entrepreneurs can make various alternative marketing strategy with the SWOT matrix.
\end{abstract}

Keywords: bamboo craft industry, the pattern of marketing, marketing strategy. 


\section{PENDAHULUAN}

Daerah Istimewa Yogyakarta merupakan salah satu destinasi wisata utama di Indonesia. Daerah Istimewa Yogyakarta menempati urutan kedua sebagai destinasi wisata utama setelah Bali. (http://www.kemendagri.go.id). Menurut Harini, et al. (2005), sektor industri pengolahan merupakan salah satu sektor unggulan di Kabupaten Sleman. Industri pengolahan yang cukup banyak di Kabupaten Sleman ialah industri pengolahan kerajinan bambu. Tanaman bambu merupakan tanaman yang cukup mudah dijumpai di Kabupaten Sleman. Data tahun 2011 menunjukkan bahwa Kabupaten Sleman memiliki hutan bambu yang paling luas dibandingkan dengan kabupaten yang lain, yaitu seluas 94,8 hektar dari total luas 220 hektar hutan bambu yang ada di DIY. (http://tempo.co.read).

Pengoptimalan potensi bambu yang ada di Kabupaten Sleman dilakukan pemerintah dengan menetapkan sentrasentra industri bambu membentuk asosiasi kerajinan bambu. Daerah sentra kerajinan bambu yang ada di Kabupaten Sleman, diantaranya yaitu Daerah Mlati, Moyudan, Minggir, dan Godean (http://m.antarayoga.com). Daerah-daerah sentra kerajinan bambu tersebut mendirikan desa-desa wisata kerajinan bambu, misalnya yaitu Desa Wisata Sendari yang ada di Kecamatan Mlati dan Desa Wisata Brajan yang ada di Kecamatan Minggir. Industri-industri kerajinan bambu mengembangkan potensi kerajinan bambu dengan unit usaha yang cukup banyak.

Banyaknya unit usaha sentra industri kerajinan bambu memiliki daya saing yang cukup tinggi. Persaingan yang cukup tinggi tersebut membutuhkan strategi pemasaran agar kegiatan industri tetap berlanjut dan berkaitan dengan keunggulan bersaing. Setiap industri

memiliki pola pemasaran yang berkaitan dengan strategi pemasaran. Seperti pada penelitian yang dilakukan oleh Imam Gozali dan CH Asta Nugraha (2015), menyatakan bahwa orientasi strategi berpengaruh secara signifikan terhadap kinerja pemasaran dan pemasaran memiliki pengaruh yang sangat signifikan terhadap keunggulan bersaing. Pola pemasaran dapat dipengaruhi oleh jenis produksi yang dipasarkan begitu juga dengan luasan pasarnya. Pola pemasaran perlu dikaji lebih dalam untuk mengetahui bagaimana bentuk saluran distribusi yang dibentuk dan kaitannya dengan keunggulan bersaing.

Pemilihan topik yaitu pola pemasaran yang dimaksud menunjukkan bentuk pola sesuai dengan teori menurut Kotler dengan kombinasi keruangan berupa daerah-daerah yang dituju pada pola tersebut. Sentra industri kerajinan bambu yang akan dikaji dapat dilakukan analisis mengenai pola pemasaran dan juga strategi pemasaran yang berkaitan dengan keunggulan bersaing. Hal tersebut menarik untuk dikaji karena banyaknya unit usaha industri masih mampu berkembang dan berlanjut walaupun persaingannya semakin meningkat.

Berdasarkan uraian di atas, tujuan penelitian ini adalah sebagai berikut:

1. Mengetahui jenis produk kerajinan bambu yang paling banyak di Kabupaten Sleman.

2. Mengetahui pola pemasaran industri kerajinan bambu di Kabupaten Sleman.

3. Mengetahui strategi pemasaran industri kerajinan bambu di Kabupaten Sleman terkait dengan keunggulan bersaing.

\section{METODE PENELITIAN}

Metode yang akan dilakukan pada penelitian ini ialah metode gabungan antara kuantitatif dan kualitatif. Metode kuantitatif digunakan untuk pengumpulan data yang berbentuk angka dengan 
menggunakan kuesioner yang selanjutnya diperkuat dengan pendekatan kualitatif. Metode kualitatif digunakan untuk memperkuat data hasil kuesioner dengan melalukan wawancara lebih mendalam kepada responden.

Populasi dalam penelitian ini adalah jumlah pengusaha industri kerajinan bambu yang ada di Kabupaten Sleman sebanyak 1.869 unit usaha. Populasi dipersempit menjadi sebanyak 653 unit usaha dengan menghitung ukuran sampel menggunakan metode Slovin menurut Sugiyono (2011:87). Rumus Slovin untuk menghitung sampel, yaitu sebagai berikut:

$$
\mathrm{n}=\frac{N}{N \cdot e^{2}+1} \text {. }
$$

Keterangan:

$\mathrm{n}$ = Ukuran sampel/jumlah responden

$\mathrm{N}=$ Ukuran populasi

$\mathrm{e}=$ Persentase kelonggaran ketelitian kesalahan pengambilan sampel yang masih bisa ditolerir, $\mathrm{e}=0.1$

Dalam rumus Slovin terdapat dua ketetapan dalam penentuan nilai e, yaitu sebagai berikut:

Nilai e $=0.1(10 \%)$ untuk populasi dalam jumlah besar

Nilai e $=0.2(20 \%)$ untuk populasi dalam jumlah kecil

Jadi rentang sampel yang dapat diambil dari metode Slovin ialah antara 10-20\% dari populasi penelitian.

Jumlah populasi dalam penelitian ini ialah sebanyak 653 unit usaha, sehingga persentase kelonggaran (e) yang digunakan ialah $10 \%$ karena termasuk dalam jumlah populasi yang besar. Sampel penelitian dapat diketahui dengan perhitungan sebagai berikut:

$$
\mathrm{n}=\frac{653}{653 \cdot(0.1)^{2}+1} .
$$

$\mathrm{n}=86,720$ dibulatkan menjadi 87 sampel.

Perhitungan sampel yang telah dilakukan dengan menggunakan metode Slovin kemudian dilakukan pengambilan sampel yang dilakukan secara Random Sampling kemudian sampel diambil secara proporsional. Sehingga metode sampling yang digunakan ialah Proporsionate Random Sampling.

Teknik analisis data yang digunakan pada penelitian ialah analisis data kuantitatif secara deskriptif. Jenis produk yang paling banyak di Kabupaten Sleman dianalisis menggunakan data primer yang dikumpulkam dari kepala desa atau dari ketua kelompok sentra industri. Pola pemasaran dianalisis secara deskriptif kuantitaif sesuai jenis pola yang terbentuk berdasarkan jenis kerajinan bambu dari data yang diolah secara persentase dan sejauh mana jangkauan dari setiap pola yang terbentuk tersebut. Strategi pemasaran dianalisis dengan idenstifikasi faktor internal dan eksternal dari Sentra kemudian dirumuskan strategi dengan menggunakan matrik SWOT.

\section{HASIL DAN PEMBAHASAN \\ Kakarteristik Pengrajin Bambu Jenis Kelamin}

Hasil penelitian di lapangan dengan menggunakan sampel menunjukkan bahwa pengusaha bambu didominasi oleh perempuan. Perempuan lebih banyak dibandingkan laki-laki karena biasanya perempuan lebih terampil dalam menganyam. Pengusaha perempuan melakukan bagian-bagian yang mudah seperti menganyam karena tidak membutuhkan tenaga yang besar dan tidak berat. Produk kerajinan bambu yang biasanya dapat dibuat oleh pengusaha perempuan misalnya besek, pincuk, souvenir, tampah, dan produk lain yang pembuatannya hanya membutuhkan keahlian menganyam. Pengusaha laki-laki biasanya membuat produk kerajinan bambu yang membutuhkan tenaga besar dan cukup berat. Produk kerajinan bambu yang biasanya dikerjakan oleh pengusaha 
laki-laki ialah mebel, kerai bambu, anyaman kepang, serta gedek.

Pengusaha bambu didominasi oleh perempuan dengan pekerjaan utamanya ialah ibu rumah tangga. Mereka beralasan bahwa pekerjaan membuat kerajinan bambu dapat dilakukan di rumah sehingga tetap dapat melakukan pekerjaan rumah dan mengasuh anak, serta mendapatkan pemasukan tambahan. Para pengusaha perempuan juga beralasan bahwa pekerjaan membuat kerajinan bambu hanya digunakan untuk mengisi waktu luang agar tidak mengganggur saat pekerjaan rumah tangga telah selesai. Sehingga, para pengusaha perempuan tidak terlalu mengutamakan pekerjaan membuat kerajinan bambu.

\section{Umur}

Pengusaha bambu di Kabupaten Sleman berkisar antara umur 25 tahun hingga 80 tahun. Pengusaha bambu di Kabupaten Sleman didominasi oleh umur lebih dari 64 tahun atau tergolong lanjut usia. Hal tersebut dapat terjadi karena pekerjaan membuat kerajinan bambu merupakan keahlian turun temurun, sedangkan anak dari para pengusaha

khususnya usia remaja sudah tidak mau meneruskan pekerjaan membuat kerajinan bambu. Selain itu, orang tuanya juga lebih memilih menyekolahkan anaknya pada jenjang yang lebih tinggi dan memilih pekerjaan lain dengan penghasilan yang lebih besar.

Perbandingan usia pengusaha lakilaki dan perempuan menunjukkan bahwa untuk laki-laki paling banyak yaitu pada usia 55-59 tahun, sedangkan untuk perempuan paling banyak yaitu pada usia diatas 64 tahun. Data menunjukkan bahwa perempuan pada setiap golongan umur selalu lebih banyak dari laki-laki. Namun, pada golongan umur 55-59, laki-laki lebih mendominasi dibandingkan dengan perempuan. Selain itu, tidak ada pengusaha laki-laki yang bergolongan umur 25-29 tahun. Tingginya jumlah pengusaha perempuan begitu juga dengan golongan umurnya dapat terjadi karena para perempuan tersebut sudah tidak mampu bekerja lagi namun tidak ingin berdiam diri saja di rumah. Sehingga mereka memilih untuk membuat kerajinan yang mudah dilakukan di rumah. Berikut pada Gambar 1 ditampilkan perbandingan umur antara laki-laki dan perempuan.

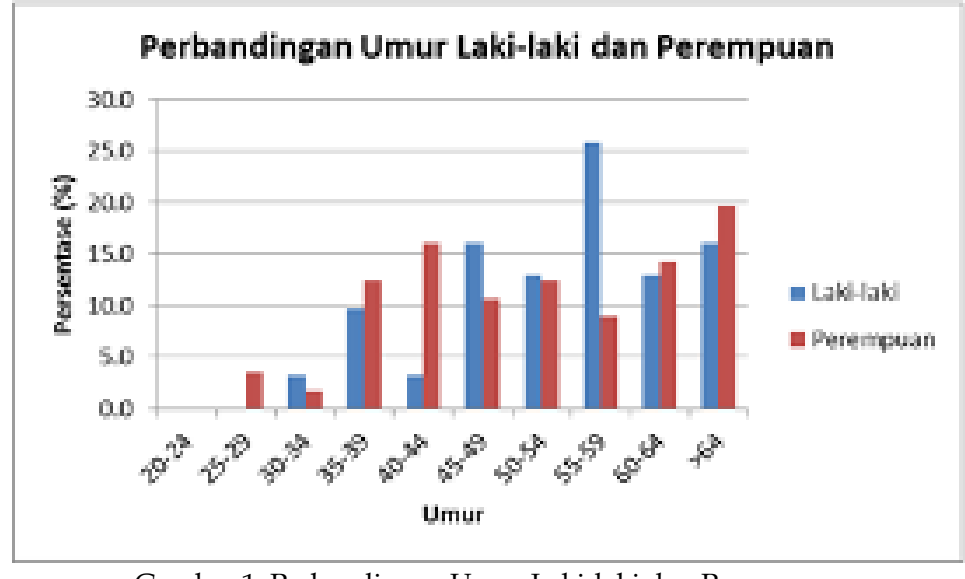

Gambar 1. Perbandingan Umur Laki-laki dan Perempuan Sumber: Pengolahan Data Primer (2018)

Pendidikan

Hasil penelitian di lapangan menunjukkan bahwa sebagian besar pengusaha bambu berpendidikan terakhir SD dan SMA. Sedangkan pengusaha yang mengenyam pendidikan hingga perguruan tinggi hanya sekitar $2 \%$ saja. Hal tersebut terjadi karena biasanya orang yang berpendidikan tinggi lebih memilih 
pekerjaan dengan pendapatan yang lebih tinggi.

Hasil penelitian menunjukkan bahwa tingkat pendidikan antara pengusaha perempuan dan laki-laki tidak jauh berbeda. Tingkat pendidikan pengusaha perempuan dan laki-laki didominasi pada jenjang sekolah dasar. Pengusaha laki-laki yang tidak sekolah lebih banyak dibandingkan dengan pengusaha perempuan. Hal tersebut dapat terjadi karena laki-laki biasanya lebih memilih untuk bekerja daripada melanjutkan pendidikan yang lebih tinggi. Berikut Gambar 2 ditampilkan perbandingan pendidikan antara pengusaha perempuan dan laki-laki.

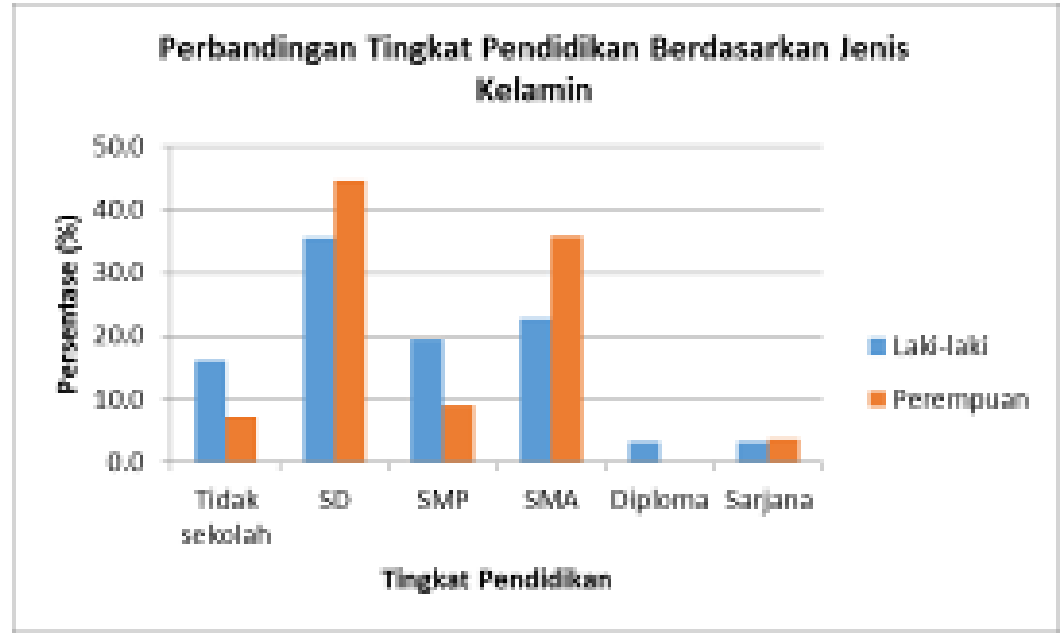

Gambar 2. Perbandingan Tingkat Pendidikan Berdasarkan Jenis Kelamin Sumber: Pengolahan Data Primer (2018)

\section{Hasil Produk Kerajinan Bambu Jenis Produk Kerajinan Bambu}

Kerajinan bambu yang ada di Kabupaten Sleman memiliki bermacam jenis, dari kerajinan bambu yang berukuran besar hingga yang berukuran kecil. Berbagai macam kerajinan bambu yang ada di Kabupaten Sleman diantaranya, yaitu mebel, anyaman/gedek, anyaman kepang, perabotan rumah tangga, dan souvenir dari bambu. Mebel bambu yang dimaskud pada penelitian ini ialah lincak, kursi malas, kursi dan meja set, tirai bembu, sekat dari bambu, serta dapat pula dibuat menjadi gazebo (gambar 3). Bahan dasar untuk membuat mebel bambu ini ialah bambu wulung dan bambu tutul.

Bambu juga dibuat menjadi kerajinan berupa gedek dan anyaman kepang (gambar 4). Gedek biasanya digunakan seperti dinding, sedangkan untuk anyaman kepang digunakan sebagai pyan atau langit-langit rumah. Cara pengerjaannya sama yaitu dengan dianyam. Kerajinan bambu juga dibuat menjadi prabotan rumah tangga seperti besek, tambir, tampah, pincuk, dan irik (gambar 5). Perabotan rumah tangga dari bambu ini pembuatannya cukup sederhana yaitu dianyam. Selain itu juga terdapat kerajinan bambu berupa souvenir. Souvenir yang terbuat dari bambu juga memiliki banyak macam produk, diantaranya yaitu tempat tisu, topi, tempat lampu, hiasan lampu, tas, kipas, tempat baju, tempat pensil, celengan, gantungan kunci, dan lain sebagainya (gambar 6). Pengerajaan souvenir dari bambu ini memiliki kerumitan masing-masing. 


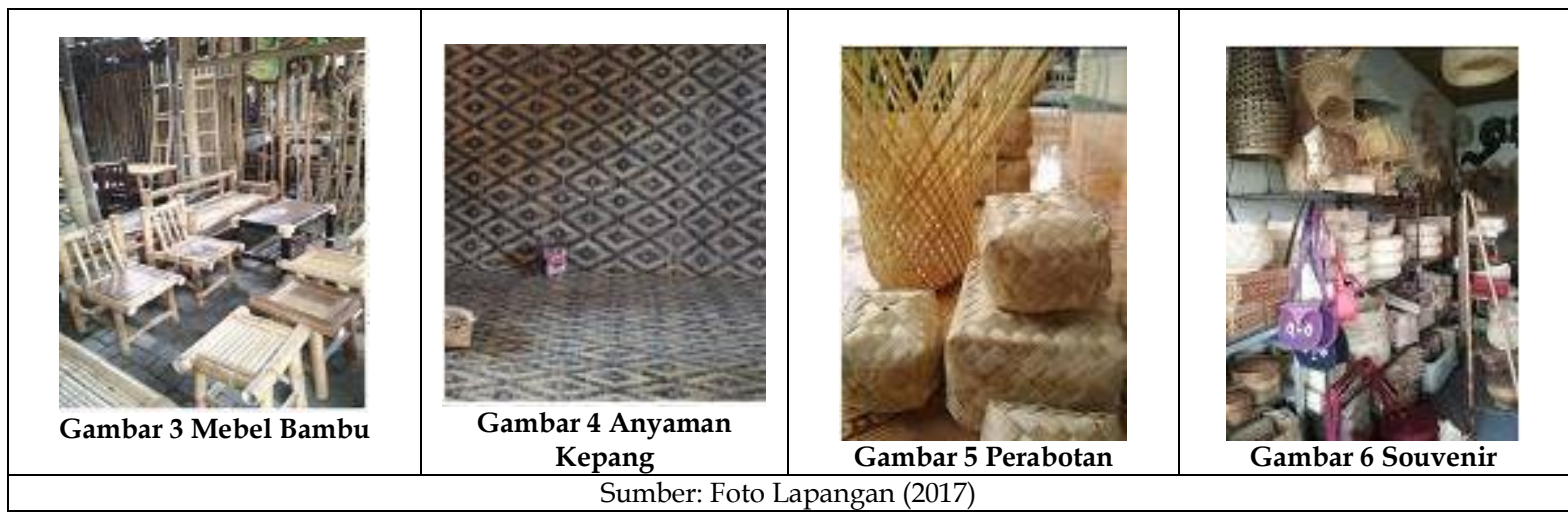

\section{Produk Kerajinan Bambu Terbanyak}

Kerajinan bambu di Kabupaten

Sleman memiliki berbagai macam jenis dan kekhasan masing-masing pada setiap sentra kerajinan bambu yang ada. Terdapat jenis kerajinan bambu yang paling banyak diproduksi oleh pengrajin bambu dari sekian banyak sentra kerajinan bambu yang ada di Kabupaten Sleman. Jenis kerajinan bambu yang paling banyak diproduksi ialah besek. Selain itu, gedek dan anyaman kepang juga termasuk kerajinan bambu yang paling banyak diproduksi selain besek.

Kerajinan bambu berupa besek banyak diproduksi karena menurut hasil penelitian di lapangan bahwa pembuatan besek paling mudah dan tidak membutuhkan modal yang besar. Proses pembuatan besek hanya membutuhkan beberapa tahap saja, yaitu membuatan ikatan bambu yang kemudian dijemur dan setelah itu cukup dianyam hingga menjadi besek. Pengusaha besek didominasi oleh perempuan. Hasil penelitian di lapangan menunjukkan bahwa pengusaha yang memilih memproduksi besek beralasan bahwa pembuatan besek dapat dilakukan di rumah sembari mengurus anak dan mengerjakan pekerjaan rumah. Para pengusaha besek juga tidak khawatir bahwa beseknya tidak laku karena pada tiap sentra selalu ada pengepul yang mengambilnya.

\section{Pola Pemasaran}

Pemasaran

produk

dapat

mengantarkan suatu produk dari produsen ke tangan konsumen. Produk dapat sampai ke tangan konsumen melalui berbagai macam pola saluran pemasaran. Menurut Johanson (2016), keberadaan saluran distribusi merupakan hal yang sangat penting, karena produsen akan sangat sulit untuk mencapai konsumen jika tidak ada perantara begitu juga dengan konsumen akan kesulitan untuk mencapai produsen. Pola saluran pemasaran industri kearjinan bambu di Kabupaten Sleman terdiri dari saluran pemasaran langsung dan saluran pemasaran tidak langsung. Saluran pemasaran secara langsung yang dimaksud ialah produk dari pengrajin dapat langsung dipasarkan ke tangan konsumen. Sedangkan saluran pemasaran secara tidak langsung membutuhkan beberapa alur untuk produk dapat sampai ke tangan konsumen. Penentuan pola pemasaran juga menggunakan beberapa referensi diantaranya penelitian oleh Adang Agustin dan Henny Myrowani (2008), serta Rifka Nur Anisa dan Indah Susilowati (2007) yang menunjukkan berbagai pola pemasaran dari tangan produsen hingga sampai ke tangan konsumen akhir.

Pola pemasaran industri kerajinan bambu di Kabupaten Sleman dibedakan berdasarkan jenis kerajinan bambu yang ada. Pola pemasaran yang ada di Kabupaten Sleman berdasarkan jenis 
produk memiliki jumlah pola yang berbeda. Pola pemasaran dibedakan berdasakan macam jenis produk kerajinan bambu yang dikelompokkan menjadi mebel bambu (gambar 7), gedek/anyaman bambu (gambar 8), perabotan rumah tangga dari bambu (gambar 9), dan souvenir dari bambu (gambar 10).

Pola pemasaran yang paling banyak digunakan pada setiap jenis produk kerajinan bambu ialah pola pemasaran I dan pola pemasaran II. Sebagian besar pengrajin sangat bergantung dengan pengecer atau pengepul. Para pengrajin tersebut mengalami kekurangan link pemasaran yang tentunya dapat menjadi kelemahan yang dimilikinya. Kekurangan link pamasaran merupakan salah satu faktor lingkungan internal yang berpengaruh terhadap strategi pemasaran seperti pada penelitian Ratih Indah Sari (2018). Tidak adanya link pemasaran menyebabkan jangkauan pemasaran dari pengusaha menjadi sangat sempit. Hal tersebut menunjukkan bahwa untuk sampai ketangan konsumen, produk tersebut perlu melewati beberapa alur. Sedangkan untuk pola yang paling menguntungkan ialah pola pemasaran IV, pengusaha memasarkan langsung kepada konsumen, namun pola pemasaran ini belum digunakan secara optimal karena keterbatasan tempat pemasaran dan cara memasarkan secara langsung.
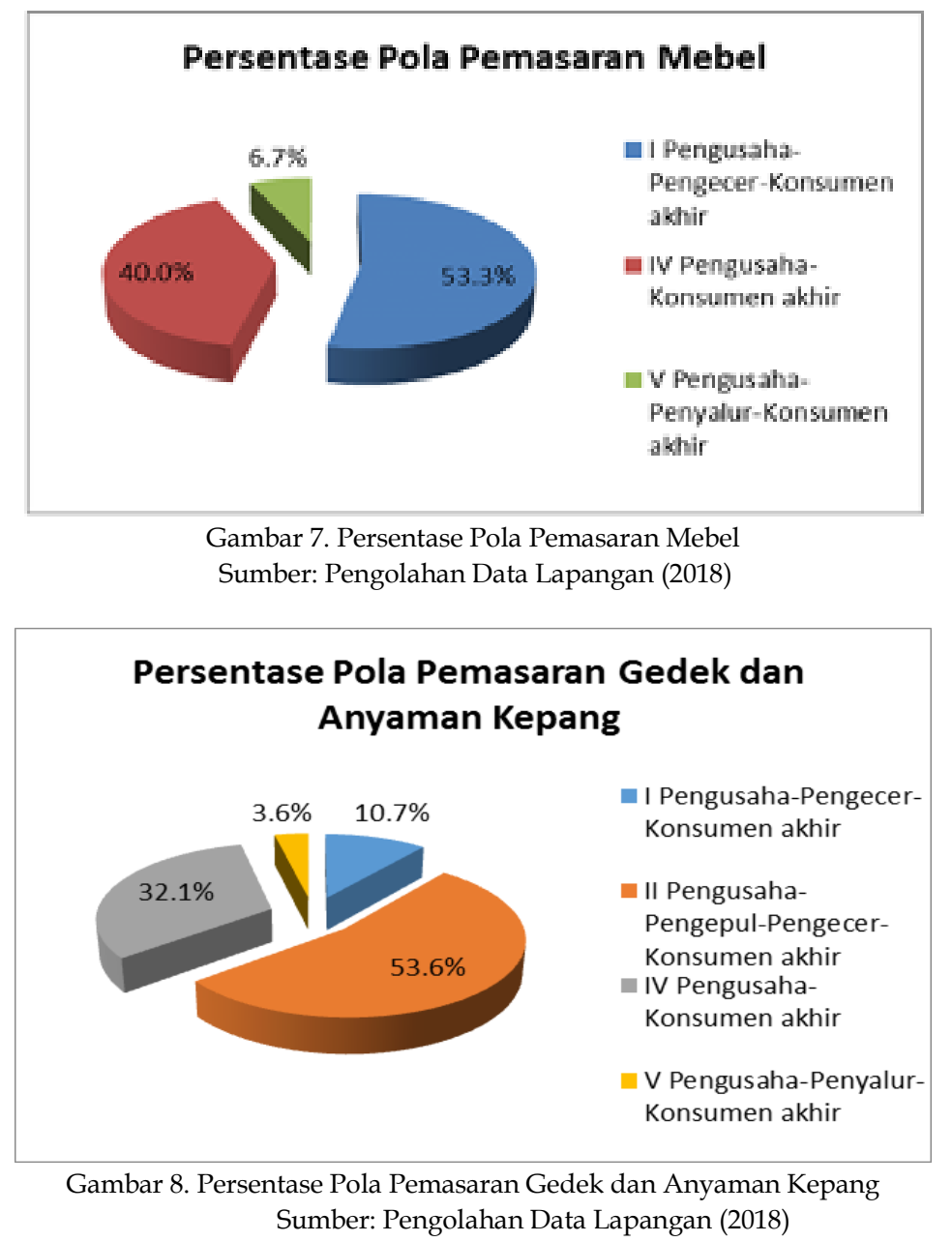

92| Vol 11 No. 1 - 2019 

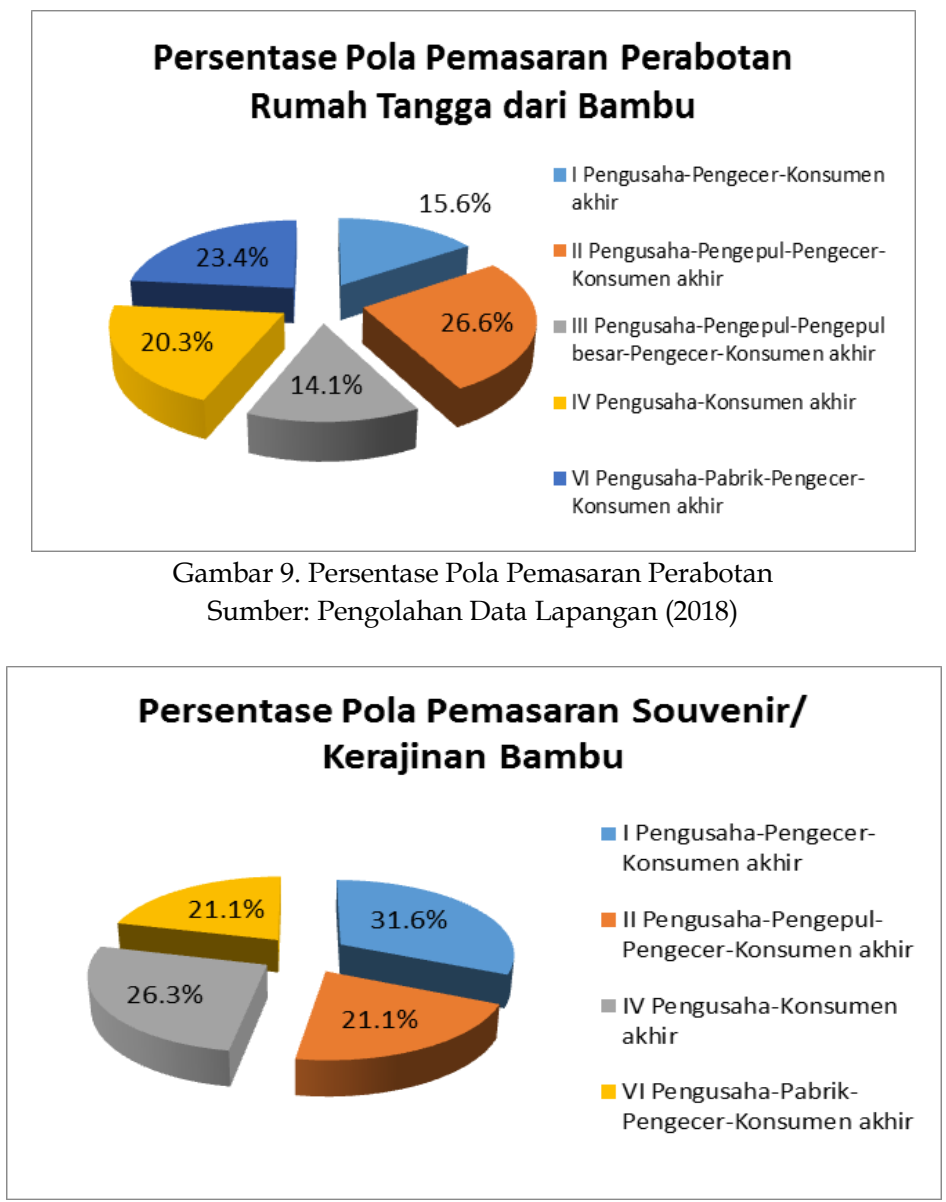

Gambar 10. Persentase Pola Pemasaran Souvenir Sumber: Pengolahan Data Lapangan (2018)

Jangkauan pemasaran pada alur setiap pola ada berbagai macam. Hasil penelitian menunjukkan bahwa pada pola pemasaran setiap jenis kerajinan bambu memiliki jangkauan yang hampir sama pada setiap alur. Seperti pada jangkauan terdapat pengepul, pada setiap jenis kerajinan bambu hanya mencapai tingkat kecamatan dan kabupaten dengan persentase paling banyak pada tingkat kecamatan. Hal tersebut dapat terjadi karena di setiap sentra kerajinan bambu selalu terdapat pengepul. Begitu juga dengan jangkauan terhadap pabrik yang hanya mencapai tingkat kecamatan dan kabupaten. Jangkauan terhadap pengecer paling banyak pada tingkat provinsi. Sedangkan jangkauan terhadap konsumen akhir mecakup wilayah yang lebih luas dan bervariasi.

\section{Distribusi Pemasaran Kerajinan Bambu}

Distribusi merupakan kegiatan pemasaran yang berusaha untuk memperlancar dan mempermudah penyampaian barang dan jasa dari produsen ke konsumen (Tjiptono, 2008). Bermacam-macam produk kerajinan bambu dapat mencapai konsumen akhir melalui berbagai alur dan perantara. Konsumen yang membeli pada pengrajin ada yang bertujuan untuk menjualnya lagi dan ada juga yang bertujuan untuk menggunakan produk tersebut.

Konsumen yang bertujuan untuk menjualnya kembali diantaranya diantaranya dapat berasal dari kecamatan yang sama, Kabupaten Sleman, Provinsi DIY, bahkan dari luar Pulau Jawa. Produkproduk kerjinan bambu di Kabupaten Sleman dijual pada showroom seperti contohnya di Sentra Kerajinan Bambu 
Sendari di Kecamatan Mlati; Sentra Kerajinan Bambu yang ada di Desa Gentan, Kecamatan Seyegan; serta Sentra Kerajinan Bambu Brajan yang ada di Kecamatan Minggir. Jenis kerajinan produk bambu tersebut daintaranya yaitu mebel bambu dan souvenir dari bambu. Selain melalui showroom, produk-produk kerajinan bambu juga dijual di pasar-pasar yang ada di Kabupaten Sleman maupun di DIY, seperti contohnya kerajinan bambu dengan jenis perabotan rumah tangga berupa besek, tambir, tumbu, truntum, serta irik. Beberapa diantara pasar-pasar yang dapat dijumpai kerajinan bambu ialah Pasar Godean, Pasar Ngijon, Pasar Beringharjo, serta pada tempat-tempat wisata seperti contohnya di Candi Borobudur. Jenis kerajinan bambu yang biasa dijual di tempat wisata ialah souvenir atau kerajinan dari bambu yang dijadikan cinderamata.
Selain itu beberapa daerah yang dekat dengan tempat wisata juga banyak menggunakan produk kerajinan bambu yang digunakan sebagai tempat oleh-oleh seperti besek kecil (pithi).

Distribusi pemasaran kerajinan bambu Kabupaten Sleman dapat mencapai daerah-daerah di Indonesia diantaranya ialah DIY, Magelang, Klaten, Solo, Semarang, Purworejo, Jakarta, Surabaya, Tasikmalaya, Palembang, Bali, dan Kalimantan. Semua jenis kerajinan bambu dapat terdistribusi sampai ke daerahdaerah tersebut. Berikut pada gambar 11, gambar 12, gambar 13, dan gambar 14 ditampilkan berturut-turut distribusi pemasaran mebel bambu, gedek/anyaman kepang, prabotan rumah tangga dari bambu, dan souvenir bambu tingkat nasional.

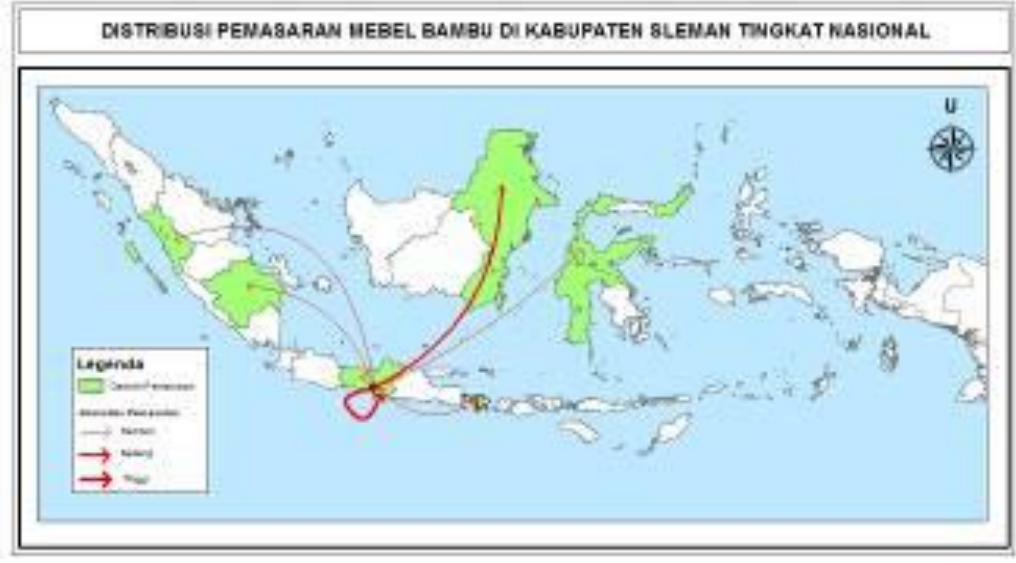

Gambar 11. Distribusi Pemasaran Mebel Bambu Tingkat Nasional Sumber: Pengolahan Lapangan (2018)

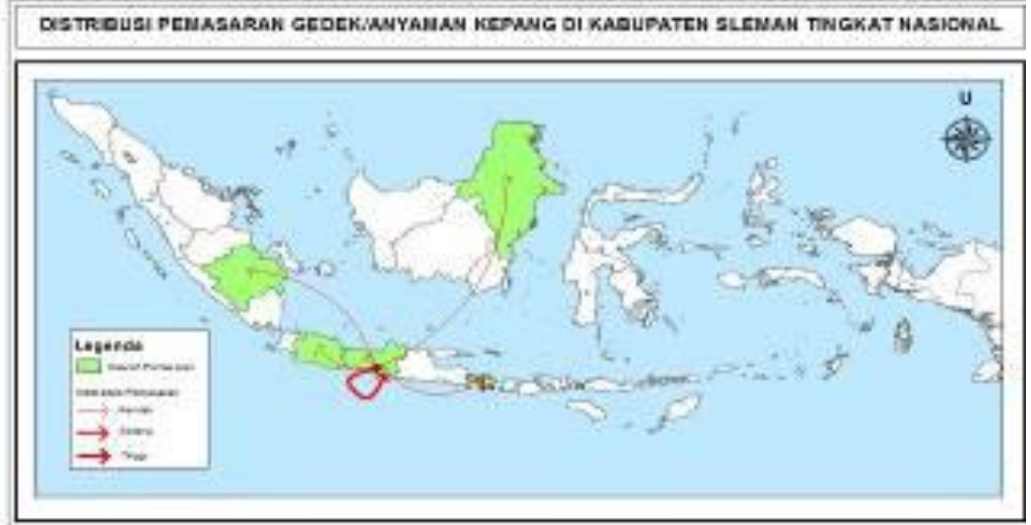

Gambar 12. Distribusi Pemasaran Gedek/Anyaman Kepang Tingkat Nasional Sumber: Pengolahan Lapangan (2018) 

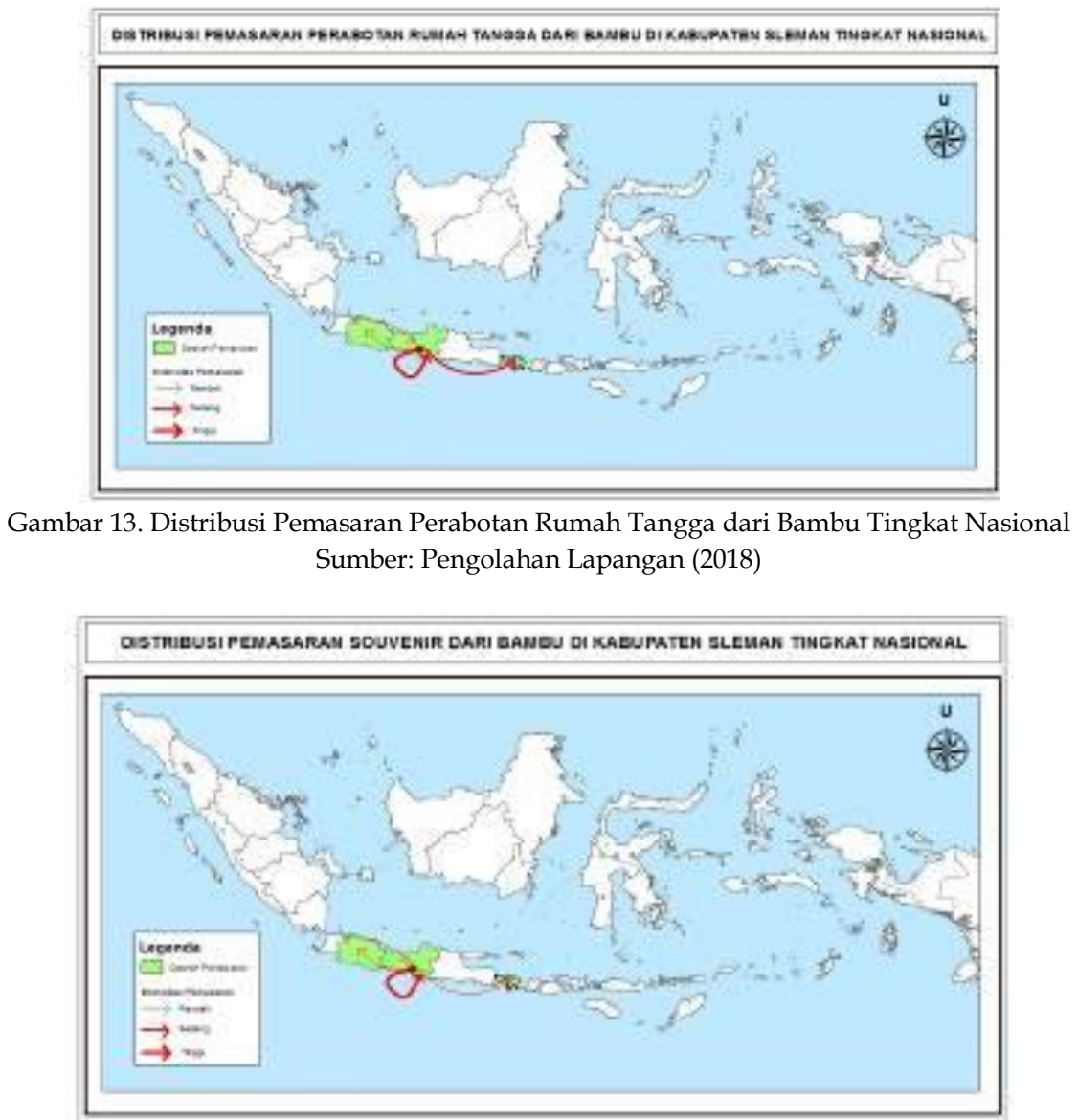

Gambar 14. Distribusi Pemasaran Perabotan Souvenir Bambu Tingkat Nasional Sumber: Pengolahan Lapangan (2018)

Gambar 11, gambar 12, gambar 13, dan gambar 14 menunjukkan bahwa DIY memiliki intensitas tujuan pemasaran yang paling banyak dibandingkan dengan daerah lain. Hal tersebut dapat terjadi karena di DIY sendiri masih banyak peminat kerajinan bambu, seperti contohnya besek yang digunakan oleh masyarakat DIY yang cukup kental kebudayaannya untuk acara seperti kenduri dan sebagai tempat oleh-oleh makanan khas DIY, gedek dan anyaman bambu sebagai langit-langit rumah, souvenir dari bambu sebagai cinderamata, serta mebel dari yang bambu masih memiliki daya tarik tersendiri terutama saat hari raya besar.

Bali juga termasuk daerah yang menerima distribusi kerajinan bambu yang cukup besar. Hasil wawancara dengan salah satu pemasok besek ke Bali mengatakan bahwa permintaan besek dari Bali cukup banyak, bahkan pada hari raya tertentu dapat mengalami kekurangan pasokan. Besek digunakan sebagai salah satu media untuk beribadah. Sehingga besek di Bali sudah seperti kebutuhan pokok. Hal tersebut menyebabkan permintaan cukup banyak. Permintaan yang cukup banyak tersebut tentunya didapat dengan mengumpulkan besek dari para pengrajin melalui pengepul-pengepul yang ada disekitarnya. Jika sudah sampai ke luar Pulau Jawa, harga pasaran akan dapat mencapai dua kali lipat dari harga aslinya. Keuntungan yang didapat jika dapat keluar dari Pulau Jawa akan lebih tinggi, namun belum banyak yang melakukan pemasaran keluar karena keterbatasan kemampuan dalam 
menggunakan teknologi dan generasi muda yang terbatas.

Distribusi pemasaran kerajinan bambu Kabupaten Sleman untuk tingkat mancanegara diantaranya, yaitu Arab, Korea, Malaysia, Belanda, dan Singapura. Kerajinan yang terdistribusi hingga ke mancanegara diantaranya mebel bambu, anyaman kepang, dan perabotan rumah tangga tertentu. Sebagian konsumen dari luar negeri ada yang merupakan pelanggan tetap. Berikut pada gambar 15, gambar 16, gambar 17, dan gambar 18 ditampilkan secara berturut-turut distribusi pemasaran mebel bambu, gedek/anyaman kepang, prabotan rumah tangga dari bambu, dan souvenir bambu tingkat internasional.

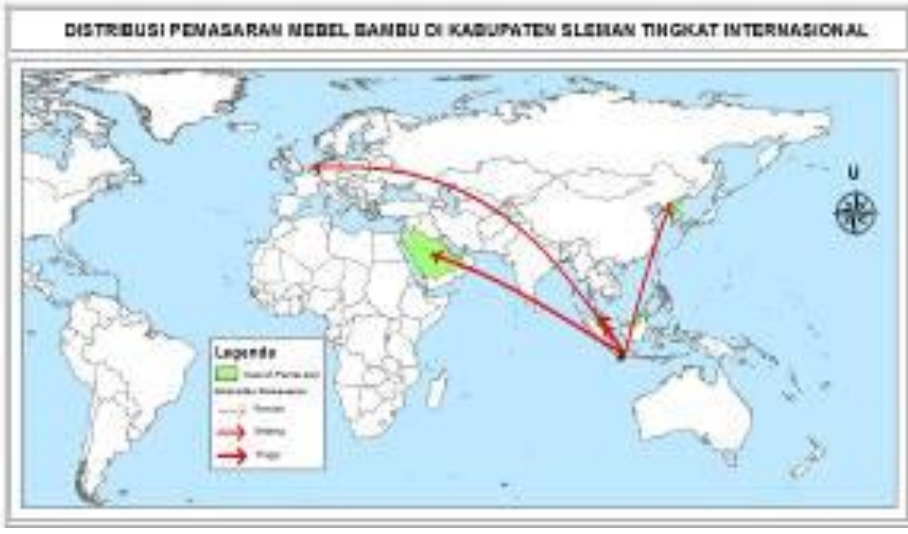

Gambar 15. Distribusi Pemasaran Mebel Bambu Tingkat Internasional Sumber: Pengolahan Lapangan (2018)

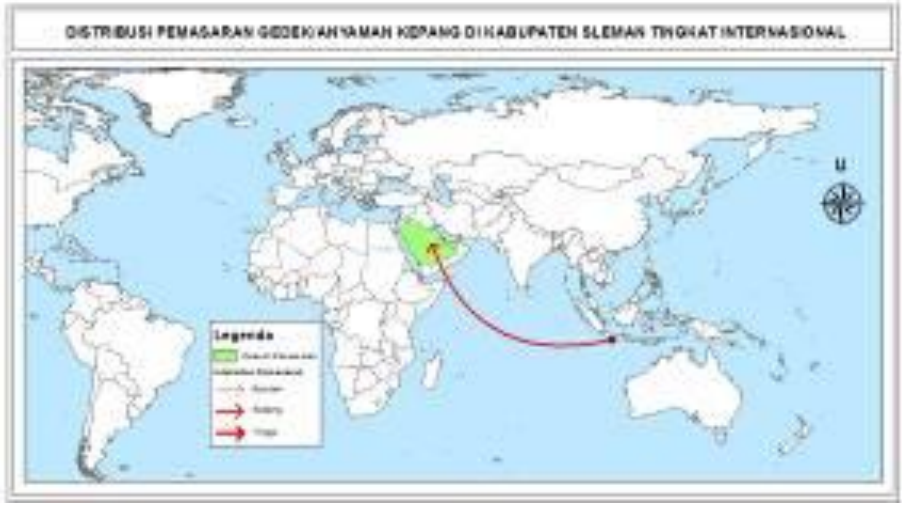

Gambar 16. Distribusi Pemasaran Gedek/Anyaman Kepang Tingkat Internasional Sumber: Pengolahan Lapangan (2018)

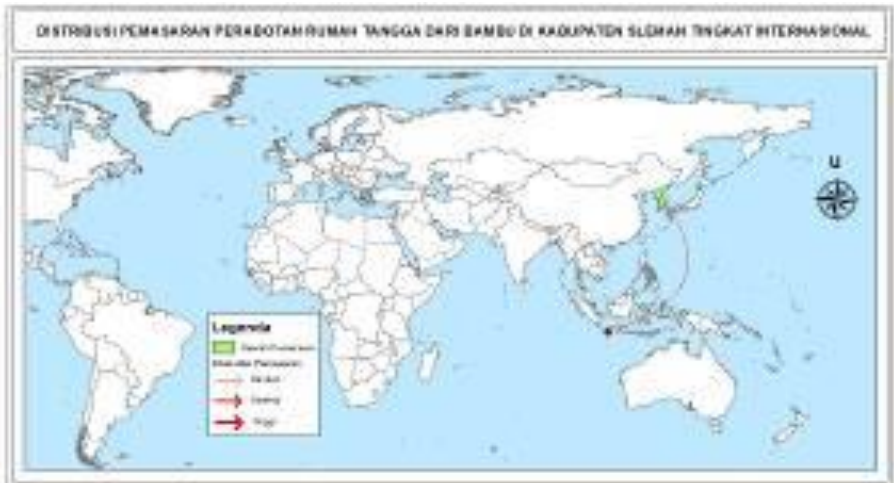

Gambar 17. Distribusi Pemasaran Perabotan Rumah Tangga dari Bambu Tingkat Internasional Sumber: Pengolahan Lapangan (2018) 


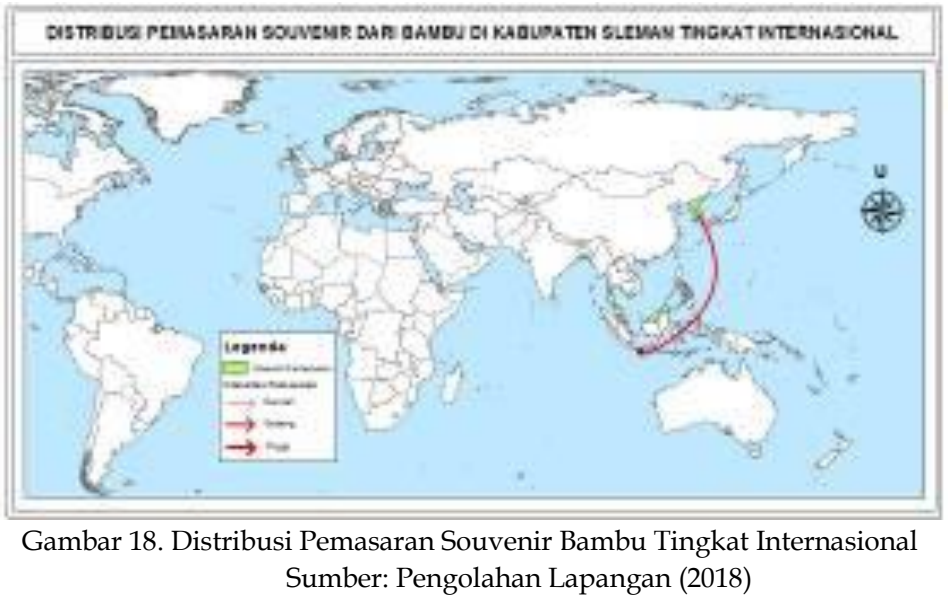

Salah satu jenis kerajinan bambu yang terdistribusi hingga ke mancanegara tersebut ialah perabotan rumah tangga yang diproduksi oleh pabrik, contohnya ialah pabrik di Dusun Malangan dengan produk bambu berupa tambir, tumbu, irik, dan lainnya. Negara-negara tersebut biasanya sudah berlangganan, khususnya berlangganan pada pabrik yang sudah cukup besar dan mampu mempromosikan secara online. Selain secara online, pemasaran juga dapat melalui suatu perantara atau penyalur yang mempromosikan beberapa sentra yang sudah bekerjasama dengannya. Penyalur tersebut membawa konsumennya kepada industri atau sentra yang dipilihnya.

Distribusi pemasaran kerajinan bambu di Kabupaten Sleman dapat dikatakan cukup luas untuk semua jenis produk kerajinan bambu. Namun, masih memerlukan perantara untuk sampai ke tangan konsumen dengan jangakuan yang luas tersebut. Pemasaran hingga sampai ke macanegara juga masih belum terlalu banyak, sehingga perlu pengoptimalan pemasaran agar dapat mencapai jangkauan yang luas.

\section{Strategi Pemasaran}

Menururt Swastha dan Irawan (2005), strategi pemasaran memainkan peran yang sangat penting dalam membangun segmen pasar. Strategi pemasaran khusus dibutuhkan untuk menguasai pasar. Pemasaran produk dapat mempengaruhi seberapa banyak produk dan seberapa luas produk yang akan terjual nantinya untuk mencapai keunggulan bersaing. Seperti pada penelitian Imam Gozali dan CH Asta Nugraha (2015) yang menyatakan bahwa orientasi strategi berpengaruh secara signifikan terhadap kinerja pemasaran dan pemasaran memiliki pengaruh yang sangat signifikan terhadap keunggulan bersaing. Adhinugroho (2002, p. 277) juga mengungkapkan bahwa salah satu karakteristik pengembangan strategi pemasaran ialah secara khusus berkaitan dengan penentuan cara bagaimana perusahaan mampu unggul dalam bersaing. Strategi pemasaran sangat dibutuhkan dalam memasarkan produk kerajinan bambu yang ada di Kabupaten Sleman. Strategi pemasaran yang digunakan dapat dilakukan dengan identifikasi faktor internal dan eksternal pada sentra kerajinan bambu di Kabupaten Sleman.

Faktor internal dan eksternal yang terdiri dari kekuatan (Strenght), kelemahan (Weakness), peluang (Opportunities), dan ancaman (Threats) yang sudah ditentukan kemudian dapat dirumuskan kedalam analisis SWOT. Berdasarkan hasil analisis dengan matriks SWOT didapatkan alternatif strategi yang dapat dilakuakn 
oleh pengusaha untuk menghadapi permasalahan pemasaran (tabel 1).

Strategi yang dirumuskan berdasarkan matriks SWOT tersebut dapat memberikan alternatif strategi pemasaran yang dapat dilakukan. Strategi yang dapat dilakukan sebagai langkah awal ialah membentuk kelompok sentra, meningkatkan promosi, dan mengajukan bantuan kepada pemerintah untuk membantu dalam memperkenalkan produk kerajinan pada masyarakat luas. Alternatif strategi tersebut diharapkan dapat memperluas dan meningkatkan pemasaran.

Tabel 1. Matriks SWOT

\begin{tabular}{|c|c|c|}
\hline Faktor Eksternal & $\begin{array}{l}\text { KEKUATAN } \\
\text { Strenght } \\
\text { 1. Lokasi sentra tersebar luas } \\
\text { 2. Keahlian turun temurun }\end{array}$ & $\begin{array}{l}\text { KELEMAHAN } \\
\text { Weakness } \\
\text { 1. Kurangnya kegiatan promosi } \\
\text { 2. Kurangnya pengusaha usia } \\
\text { muda } \\
\text { 3. Pemasaran online belum } \\
\text { optimal } \\
\text { 4. Penggunaan teknologi lemah } \\
\text { 5. Jangkauan pemasaran yang } \\
\text { kurang luas }\end{array}$ \\
\hline $\begin{array}{l}\text { PELUANG } \\
\text { Opportunities } \\
\text { 1. Pasar luas bagi sentra yang } \\
\text { sudah dikukuhkan oleh } \\
\text { pemerintah }\end{array}$ & $\begin{array}{l}\text { S-O } \\
\text { 1. Membuat paket wisata pada } \\
\text { sentra } \\
\text { 2. Meningkatkan sarana dan } \\
\text { prasarana pendukung } \\
\text { 3. Mengajukan pengesahan } \\
\text { sentra untuk sentra yang } \\
\text { belum dikukuhkan }\end{array}$ & $\begin{array}{l}\text { 1. Mengikuti pameran-pameran } \\
\text { yang ada untuk } \\
\text { memperkenalkan produk } \\
\text { 2. Mengadakan pelatihan } \\
\text { pemasaran online } \\
\text { 3. Perekrutan tenaga kerja } \\
\text { generasi muda khsusunya } \\
\text { bagian marketing }\end{array}$ \\
\hline $\begin{array}{l}\text { ANCAMAN } \\
\text { Threats } \\
\text { 1. Kurangnya pengetahuan } \\
\text { masyarakat terhadap inovasi } \\
\text { baru } \\
\text { 2. Regenerasi pengusaha bambu } \\
\text { 3. Persaingan antar sentra }\end{array}$ & $\begin{array}{l}\text { S-T } \\
\text { 1. Membuat pelatihan inovasi } \\
\text { baru dan sosialisai pentingnya } \\
\text { inovasi } \\
\text { 2. Mengadakan pameran inovasi } \\
\text { baru } \\
\text { 3. Mengadakan karnaval untuk } \\
\text { memperkenalkan inovasi baru } \\
\text { 4. Meningkatkan keterampilan } \\
\text { SDM }\end{array}$ & $\begin{array}{l}\text { W-T } \\
\text { 1. Membentuk kelompok sentra } \\
\text { 2. Penetapan harga pasar } \\
\text { 3. Memperluas pasar } \\
\text { 4. Pelatihan menganyam bagi } \\
\text { generasi muda }\end{array}$ \\
\hline
\end{tabular}

Sumber: Pengolahan Data Lapangan, 2018

\section{KESIMPULAN}

1. Jenis produk kerajinan bambu di Kabupaten Sleman terdiri dari mebel bambu, gedek dan anyaman kepang, perabotan rumah tangga dari bambu, dan souvenir dari bambu. Jenis produksi kerajinan bambu yang paling di Kabupaten Sleman ialah besek. Kerajinan besek pengerjaannya mudah dan ringan serta didominasi oleh pengusaha perempuan sesuai dengan karakteristik sosial pengusaha kerajinan bambu yang didominasi pengusaha perempuan.

2. Pola pemasaran kerajinan bambu yang ada di Kabupaten Sleman terbagi menjadi enam pola pemasaran. Pola pemasaran yang digunakan oleh pengusaha berdasarkan jenis produk kerajinan bambu bervariasi. Jangkauan distribusi kerajinan bambu dapat 
mencapai tingkat nasional dan internasional.

3. Strategi pemasaran yang dirumuskan dengan menggunakan matrik SWOT menghasilkan beberapa alternatif strategi yang dapat digunakan oleh penguasaha. Langkah awal yang dapat dilakukan ialah membentuk kelompok sentra, meningkatkan promosi, dan mengajukan bantuan kepada pemerintah untuk membantu dalam memperkenalkan produk kerajinan pada masyarakat luas yang diharapkan dapat memperluas dan meningkatkan pemasaran.

\section{SARAN}

1. Terbentuknya berbagai pola pemasaran dapat dilakukan penelitian lebih lanjut mengenai rantai nilai untuk mengetahui margin pemasaran dari pengrajin hingga ke konsumen akhir.

2. Terbentuknya jangkauan pemasaran yang beragam dalam penelitian ini dapat dilakukan penelitian lebih lanjut mengenai apa saja faktor-faktor yang dapat memperluas jangkauan pemasaran.

3. Data sentra kerajinan sangat penting untuk mengatahui persebarannya sehingga perlu adanya pendataan yang akurat hingga ke pusat, serta kesesuaian data antara sentra yang dimaksud dengan data yang ada di pusat.

\section{DAFTAR PUSTAKA}

Adhinugroho, H. (2002). Sistem Informasi Pemasaran dan Environmental Scanning Pengaruhnya Terhadap Kualitas Layanan, Keunggulan Bersaing, dan Pertumbuhan Pelanggan. Jurnal Sains Pemasaran Indonesia, 1(3), 275-291.

Agustian, A., \& Mayrowani, H. (2008). Pola Distribusi Kentang di Kabupaten Bandung, Jawa Barat. Jurnal Ekonomsi Pembangunan, 9(1), 96-106.
Anisah, R.N., \& Susilowati, I. (2007). Kajian Manajemen Pemasaran Ikan Pindang Layang di Kota Tegal. Jurnal Pasir Laut, 3(1), 1-18.

Gozali, I., \& Nugraha, C.H.Asta. (2015). Analisis Kinerja Pemasaran untuk Mencapai Keunggulan Bersaing (Studi pada Centra Industri Pakaian Batik di Pekalongan). Prosiding Seminar Nasional \& Call For Papers 2015. Optimalisasi Peran Industri Kreatif dalam Menghadapi Masyarakat Ekonomi ASEAN. ISBN:978-60214119-1-9. Hal. 108-122. Semarang.

Harini, R., Giyarsih, S.R., \& Budiani, S.R. (2005). Analisis Sektor Unggulan dalam Penyerapan Tenaga Kerja di Daerah Istimewa Yogyakarta. Majalah Geografi Indonesia, 19(1), 1-20.

Johanson, D. (2016). Analisis Efisiensi Pola Distribusi Hasil Penangkapan Ikan Nelayan Kecamatan Kahayan Kuala Kabupaten Pulau Pisang. Jurnal Sains Manajemen, $V(1), 81-93$.

Kementerian Dalam Negeri. (2014). Profil Provinsi Daerah Istimewa Yogyakarta. Cited in http://wwww.kemendagri.go.id/pages/profil -daerah/provinsi/detail/34/di-yogyakarta. [19 September 2017].

Pemerintah Kabupaten Sleman. (2013). Asosiasi Bambu Sembada Sleman Dikukuhkan. Cited in http://m.antarayoga.com/berita/326921/as osiasi-sentra-bambu-sembada-slemandikukuhkan. [ 19 Juli 2017].

Pito, A. R. (2013). Yogyakarta Kembangkan Sejuta Hektar Hutan Bambu. Tempo.co Politik, 31 Januari 2013. Cited in http://tempo.co.read/news/2013/01/31/20 6458291/YogyakartaKembangkan-Sejuta- 
Hektar-Hutan-Bambu. $[19$ September 2017].

Sari, R.I., \& Budiani, S.R. (2018). Analisis Strategi Pemasaran Industri Tenun di Desa Gamplong Kabupaten Sleman. Majalah Geografi Indonesia, 32(1), 98107.

Sugiyono. (2011). Metode Penelitian Kuantitatif, Kualitatif, dan $R \mathcal{E} B$. Bandung: Alfabeta.

Tjiptono, F. (2008). Startegi Pemasaran. Edisi III. Yogyakarta: Andi. 